\title{
Isolation and Partial Characterization of an Antiviral Proteolytic Fraction from the Venom of Echis Carinatus Sochureki
}

\author{
G. Borkow ${ }^{1 *}$, D. Marco ${ }^{2}$ and M. Ovadia ${ }^{2}$ \\ ${ }^{1}$ Cupron Inc. Hameyasdim 44, Gibton 76910, Israel, and ${ }^{2}$ Department of Zoology, George S. Wise Faculty of Life \\ Sciences, Tel Aviv University, Ramat Aviv 69978, Israel
}

\begin{abstract}
The venom of the viper Echis carinatus sochureki suppresses the hemolytic activity of Sendai virus on human erythrocytes, when pre-incubated with the virions prior to their binding to cells. A fraction (C1), with an $\mathrm{IC}_{50}$ of 1.25 $\mu \mathrm{g} / \mathrm{ml}$, was isolated from the venom. Fraction $\mathrm{C} 1$ possesses strong azocollase, azocaseinase and gelatinase activity. The proteolytic and anti-hemolytic potency of $\mathrm{C} 1$ depends on the period and temperature of incubation. Its antiviral activity is inhibited by Sodium-EDTA but not by PMSF. SDS PAGE of Sendai virus incubated with fraction C1 shows disappearance of several of the virion high molecular weight bands. We suggest that inhibition of the hemolytic activity of the virions is probably a result of the cleavage of viral surface proteins, such as the hemagglutinin-neuraminidase glycoprotein found on the virion envelope that mediates the absorption of the virus to cells.
\end{abstract}

\section{INTRODUCTION}

Snake venoms are complex mixtures of toxins and enzymes with different activities on many biological systems. Among other components they include cytotoxins [1-3], antibacterial [4] and anti-viral factors [5-7]. Among several viperid snake venoms screened for antiviral effects, the snake venoms of Echis carinatus suchureki and Echis coloratus were found to abolish the hemolysis of human erythrocytes caused by Sendai virus [5]. The active antiviral factor found in the venom of Echis coloratus was isolated and characterized [6]. This factor, termed Echinibin-1, is a 25$\mathrm{kDa}$ metalloproteinase glycoprotein, which interferes with the virus adsorption to the cells resulting in the suppression of the hemolytic, hemagglutinating and lethal activities of Sendai virus.

Sendai virus is an enveloped virus, which belongs to the Parainfluenza family. This group of viruses includes pathogens that can cause serious respiratory tract diseases [8]. Parainfluenza is one of three genera of the Paramyxoviridae family, which includes additional important human pathogens, such as Measles, Mumps, and Respiratory Syncytial Virus (RSV). The first two stages, which allow the penetration of these enveloped viruses into animal cells, are the attachment and the fusion of the virions with the target cell membrane. These steps are mediated by two glycoproteins found on the virion envelope - the hemagglutininneuraminidase (HN) and the fusion (F) proteins [9]. Inhibition of any of these two steps results in the loss of virus infectivity.

The present work deals with the isolation and partial characterization of fraction found in the venom of the snake Echis carinatus sochureki that suppresses the hemolytic activity of Sendai virus.

\footnotetext{
*Address correspondence to this author at the Cupron Inc. Chemtex, P.O. Box No. 23311, Jerusalem 91233, Israel; Tel: 972-8-546-611287; Fax: 9728-9491254; E-mail: gadi@cupron.com
}

\section{MATERIALS AND METHODS}

Venom

The venom of Echis carinatus sochureki was purchased from Latoxan Laboratories, 05150 Rosans, France.

\section{Virus}

Sendai virus ( $\mathrm{Z}$ strain) was injected into the allantoic sac of 10-11 day-old chicken embryo, harvested after $48 \mathrm{~h}$ from the allantoic fluid and stored at $-70^{\circ} \mathrm{C}$ until used.

\section{Blood}

Fresh, human blood was obtained from a blood bank and stored for up to one month at $4^{\circ} \mathrm{C}$. Prior to use, erythrocytes were washed five times with phosphate buffer saline, $\mathrm{pH} 7.2$ (PBS), and were diluted to $2 \%(\mathrm{v} / \mathrm{v})$ with the same buffer $\left(10^{8}\right.$ cells per $\left.\mathrm{ml}\right)$.

\section{Estimation and Concentration of Proteins}

Protein content was estimated by measuring the absorbance at $280 \mathrm{~nm}$ in a Gilford U.V. spectrophotometer, using a value of $\mathrm{A} 1 \%_{280}=14$.

\section{Hemolysis Assay}

One milliliter of washed $2 \%$ erythrocytes $\left(10^{8}\right.$ cells $)$ were incubated with Sendai virion aliquots for $15 \mathrm{~min}$ at $4^{\circ} \mathrm{C}$ and then washed twice with cold PBS. The pellets were resuspended in $1 \mathrm{ml}$ PBS and incubated for another two hr at $37^{\circ} \mathrm{C}$ in a shaking bath (90 strokes/min), followed by centrifugation at $1000 \mathrm{x}$ g. The hemolysis was determined by measuring the absorbance of the supernatant at $540 \mathrm{~nm}$.

\section{Determination of Antiviral Activity}

The effect of the venom and the various fractions on the viral activity was tested in three series of experiments. All 
experiments were done in duplicates, and at least in three separate sets, as follows:

\section{Pre-Treatment of the Virus with the Venom}

Samples of Sendai virions, each containing 70 Hemagglutinating Units (HAU), were incubated with various concentrations of the venom or its fractions in $50 \mu \mathrm{l}$ PBS for $1 \mathrm{~h}$ at $37^{\circ} \mathrm{C}$. Then one $\mathrm{ml}$ containing $10^{8}$ washed human erythrocytes was added to each tube and the hemolysis assay was carried out as described above. As controls, erythrocytes were incubated with the venom or venom fractions only without virus, or with sample of Sendai virions in PBS without venom.

\section{Pre-Absorption of the Erythrocytes with Sendai Virus before the Addition of Venom}

Duplicate samples of $10^{8}$ washed human erythrocytes were incubated with the Sendai virions for $15 \mathrm{~min}$ at $4^{\circ} \mathrm{C}$. Excess virus was removed by washing twice with cold PBS and the pellets were resuspended in $1 \mathrm{ml}$ of cold PBS. Various concentrations of the venom were then added and the mixtures were incubated for another $2 \mathrm{hrs}$ at $37^{\circ} \mathrm{C}$ in a shaking bath and centrifuged. The hemolysis was determined by measuring the absorbance of the supernatant at $540 \mathrm{~nm}$.

\section{Pre-Treatment of the Erythrocytes with Venom before the Addition of the Virus}

Duplicate samples of $10^{8}$ washed human erythrocytes were incubated with various concentrations of the venom in one $\mathrm{ml}$ PBS for one $\mathrm{hr}$ at $37^{\circ} \mathrm{C}$. The cells were then washed twice with PBS before the addition of Sendai virions to each erythrocyte sample and the hemolysis was tested as described above. As controls, untreated erythrocytes were incubated with PBS or with the virus only.

\section{Proteolytic Activity}

Proteolytic activity was tested on three different substrates: azocoll, azocasein and gelatin. Aliquots containing different concentrations of the venom fractions were incubated separately with $10 \mathrm{mg}$ of azocoll (insoluble dye - protein complex), in one $\mathrm{ml}$ of $0.1 \mathrm{M}$ phosphate buffer, $\mathrm{pH} 7.2$, for $2 \mathrm{hr}$ at $37^{\circ} \mathrm{C}$ in a shaking bath (120 strokes per min). The mixtures were centrifuged and the azocollase activity was estimated by measuring the absorbance of the clear supernatant at $520 \mathrm{~nm}$. Caseinase activity was determined by incubating various concentrations of the venom fractions with $2 \%$ azocasein in one $\mathrm{ml}$ of $0.4 \mathrm{M}$ Tris buffer, $\mathrm{pH} 8.5$, for $2 \mathrm{hr}$ at $37^{\circ} \mathrm{C}$ in a shaking bath. The reaction was stopped by precipitating the undigested azocasein with 5\% final concentration of trichloroacetic acid (TCA). The mixtures were centrifuged and the proteolytic activity was estimated by measuring the absorbance of the clear supernatant at $400 \mathrm{~nm}$. Gelatinase activity was examined as follows: $50 \mu \mathrm{l}$ PBS containing $80 \mu \mathrm{g}$ of the isolated active fractions were applied to an undeveloped black and white Kodak film and incubated for $2 \mathrm{hr}$ at $37^{\circ} \mathrm{C}$ in a moist chamber. The film was then washed thoroughly with tap water. A transparent spot on an opaque background indicated gelatin digestion. Trypsin alone $(125 \mu \mathrm{g} / \mathrm{ml})$ was used as control.

\section{Purification of the Antiviral Factors from the Crude Venom}

\section{(i) Gel filtration on a Sephadex G-50}

$100 \mathrm{mg}$ of lyophilized Echis sochureki venom were dissolved in $1 \mathrm{ml}$ of phosphate buffer, $0.01 \mathrm{M}, \mathrm{pH} 7.2$, centrifuged at $5000 \times \mathrm{g}$ and applied on a Sephadex G-50 column $(1 \mathrm{x} 90 \mathrm{~cm})$. The elution was performed with the same buffer at a flow rate of $2 \mathrm{ml} / \mathrm{cm}^{2} / \mathrm{h}$ and the effluent was collected in 2-ml fractions. Each fraction was examined for antiviral activity as described above.

\section{(ii) Chromatography on CM-Sepharose}

The active fractions of the previous step were pooled and subjected to column chromatography on CM-Sepharose $(5 \mathrm{x}$ $0.6 \mathrm{~cm})$ equilibrated with $0.01 \mathrm{M}$ phosphate buffer $(\mathrm{pH} 7.2)$. The column was washed by the same phosphate buffer before elution with a gradual increase of salt concentration (up to $0.3 \mathrm{M} \mathrm{NaCl}$ ). Each fraction was examined for antiviral activity as described above.

\section{(iii) Chromatography on DEAE-Sepharose}

The active fractions of the previous step were pooled and subjected to column chromatography on DEAE-Sepharose $(10 \times 1.0 \mathrm{~cm})$ equilibrated with $0.01 \mathrm{M}$ phosphate buffer $(\mathrm{pH}$ 7.2). The column was washed by the same phosphate buffer before elution with a gradual increase of salt concentration (up to $0.3 \mathrm{M} \mathrm{NaCl}$ ). Each fraction was examined for antiviral activity as described above.

\section{$\underline{\text { SDS-PAGE }}$}

The antiviral fraction alone $(10 \mu \mathrm{g})$, virus alone (corresponding to $70 \mathrm{HAU}$ ), or virus (70 HAU) incubated for various periods of time with the antiviral fraction $(10 \mu \mathrm{g})$, were run separately on $15 \%$ polyacrylamide gel in the presence of $0.1 \%$ sodium dodecyl sulfate (SDS) dissolved in $0.05 \mathrm{M}$ Tris-glycine buffer, $\mathrm{pH}$ 8.3. under denaturating conditions according to the SDS polyacrylamide gel electrophoresis (PAGE) method [10]. The gel was stained with $0.025 \%$ Coomassie brilliant blue in $25 \%$ isopropanol and $10 \%$ acetic acid.

\section{RESULTS}

\section{Antiviral Activity of Echis Carinatus Sochureki Crude Venom}

The effect of the crude venom on the hemolytic activity of Sendai virus was examined on human erythrocytes in three different experimental settings as described in Materials and Methods.

The hemolytic activity of the virions was inhibited in a dose response and temperature dependant manner when the virions were pre-treated with the venom of Echis carinatus sochureki (Fig. 1). The inhibitory concentration that reduced the virus hemolytic activity by $50 \%\left(\mathrm{IC}_{50}\right)$ was $30 \mu \mathrm{g} / \mathrm{ml}$ when the virions were pre-incubated with the venom for $2 \mathrm{hr}$ at $37^{\circ} \mathrm{C}$. However, prolonged incubation for up to $24 \mathrm{hr}$ at $37^{\circ} \mathrm{C}$ or at $30^{\circ} \mathrm{C}$ resulted in an $\mathrm{IC}_{50}$ of $1 \mu \mathrm{g} / \mathrm{ml}$ and $5 \mu \mathrm{g} / \mathrm{ml}$, respectively. Comparable results, showing less that $5 \%$ deviation in the IC50 values, were obtained in two additional 
similar experiments. The effect of the temperature and the time of incubation on the $\mathrm{IC}_{50}$ indicated that the antiviral activity of the venom was probably a result of enzymatic digestion of a viral component(s).

Addition of the venom to erythrocytes, which were preabsorbed with Sendai virus, did not affect the hemolysis caused by the pre-absorbed virions. Similarly, pre-treatment of the erythrocytes by up to $100 \mu \mathrm{g} / \mathrm{ml}$ of the venom before the addition of the virus did not affect the hemolysis caused by the Sendai virions. These results indicated that the venom inhibited the hemolytic activity of the virus by interacting with a free (non-attached) viral particle rather than with a cell component.

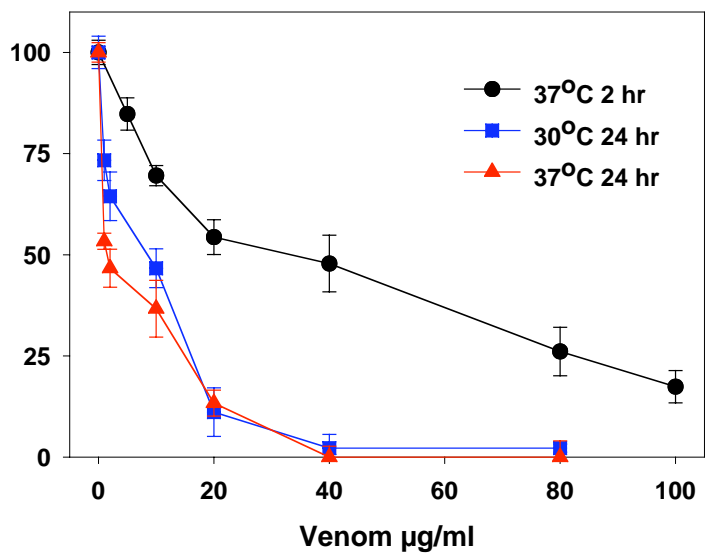

Fig (1). Effect of temperature and the incubation period on the antiviral activity. $100 \mu \mathrm{l}$ samples containing $70 \mathrm{HAU}$ of Sendai virus with various venom concentrations in $0.01 \mathrm{M}$ phosphate buffer, $\mathrm{pH} 7$, were incubated at $30^{\circ} \mathrm{C}$ or $37^{\circ} \mathrm{C}$ for $2 \mathrm{hr}$ or $24 \mathrm{hr}$. An hemolysis assay was carried out with the mixture, as described in the Methods section.

\section{Isolation of the Active Factor from the Venom}

We assumed that the venom active factor is a protein. This assumption was based on the above results, which indicated that the active fraction is an enzyme. In addition, the fact that Echinibin-1, the antiviral factor that we have previously isolated from the venom of a closely related snake, Echis coloratus, is a protein also contributed to this assumption [6]. Therefore, the various components of the Echis sochureki venom were fractionated by protein size chromatography, followed by ion and cation exchange chromatography of the antiviral active fractions (as detailed in the methods section).

Following chromatography on G-50 Sephadex, the antiviral activity was found in fractions $38-45$ (Fig. 2A) with a 12 fold increase in the specific activity of the pool (Table 1). After subjecting the pooled fractions $38-45$ to a CMSepharose column, the antiviral activity was found in the first peak $\mathrm{C} 1$ that was not absorbed to the column (Fig. 2B). This peak showed a further 2-fold increase in the specific activity (Table 1). Further fractionation of Fraction $\mathrm{C} 1$ on a DEAESepharose column resulted in 3 peaks. None of the three peaks showed antiviral activity, unless they were pooled together, obtaining a similar specific activity as fraction $\mathrm{C} 1$.
Table 1. Isolation of the Antiviral Factor

\begin{tabular}{|c|c|c|c|c|c|}
\hline $\begin{array}{c}\mathbf{I C}_{50} \text { Step } \\
(\boldsymbol{\mu g} / \mathbf{m l})\end{array}$ & Total & $\begin{array}{c}\text { Protein } \\
(\mathbf{m g})\end{array}$ & $\begin{array}{c}\text { Specific } \\
\text { Activity }\end{array}$ & $\begin{array}{c}\text { Total } \\
\text { Units }\end{array}$ & $\begin{array}{c}\text { Yield \% of } \\
\text { Recovery }\end{array}$ \\
\hline \hline $\begin{array}{c}\text { Crude } \\
\text { Venom }\end{array}$ & 100 & 30 & 1 & 3333 & 100 \\
\hline G-60 (S2) & 6.25 & 2.5 & 12 & 2500 & 75 \\
\hline $\begin{array}{c}\text { CM- } \\
\text { Sepharose } \\
(\mathrm{C} 1)\end{array}$ & 1.5 & 1.2 & 24 & 1200 & 36 \\
\hline
\end{tabular}

The $\mathrm{IC}_{50}$ was determined by incubating $70 \mathrm{HAU}$ of fraction at each step of purification for $2 \mathrm{hr}$ at $37^{\circ} \mathrm{C}$ described in the Methods. The standard deviation was Sendai virus with various concentrations of the antiviral and the mixture was examined in a hemolysis assay, as less than $5 \%$.
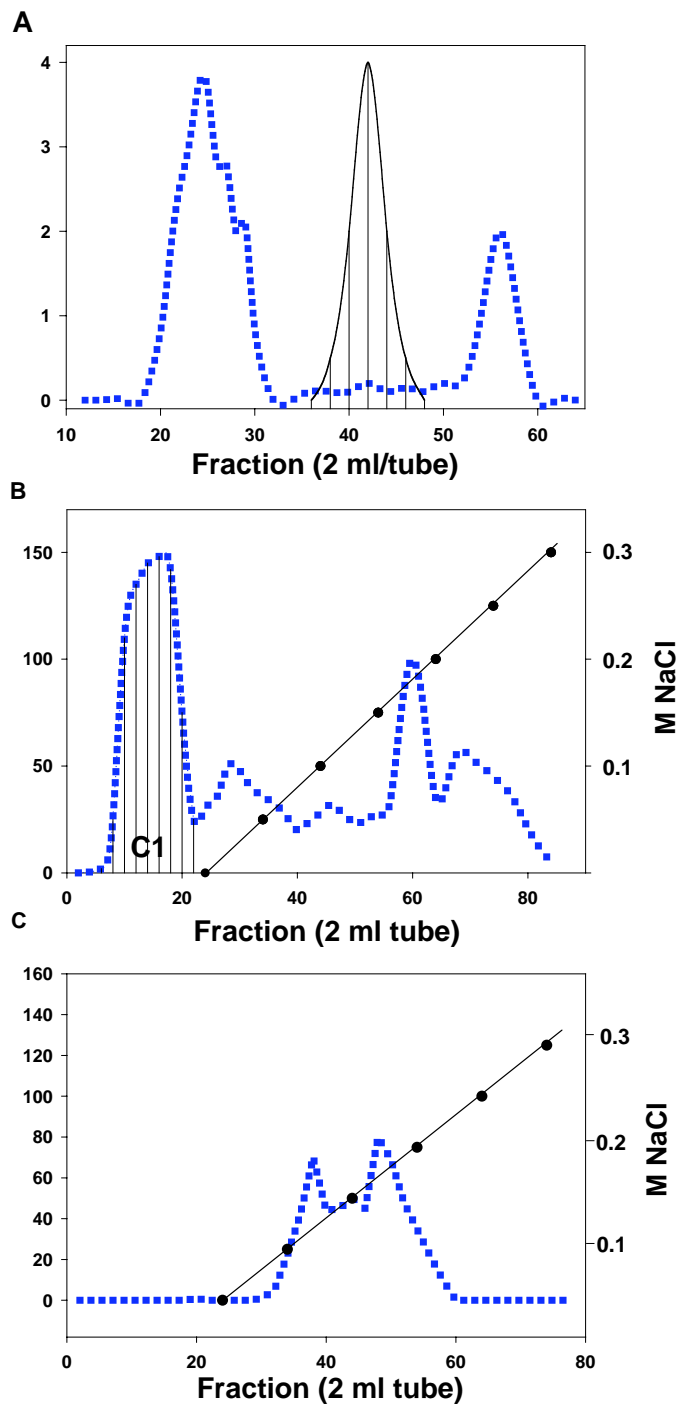

Fig (2). Isolation of the antiviral fractions from the venom of Echis carinatus sochureki. A) Whole venom was applied to a Sephadex G-50 column. The antiviral activity was found in fractions 38-45 (shadowed peak). B) The pooled fractions 38-45 (S2) of the previous step were subjected to CM-Sepharose column. The antiviral activity was found in the first peak $\mathrm{C} 1$ (shadowed peak) that was not absorbed to the column. C) Fraction $\mathrm{C} 1$ of the previous step was subjected to a DEAE-Sepharose column. None of the eluted fractions showed antiviral activity. 


\section{Characterization of the Active Fraction}

SDS-PAGE electrophoresis of fraction $\mathrm{C} 1$ revealed one main band of $23.5 \mathrm{kDa}$ and two other weaker bands with molecular weights of 27.5 and $18 \mathrm{kDa}$. The antihemolytic activity was thermo-labile: while no effect was observed on the antihemolytic activity of fraction $\mathrm{C} 1$ heated up to $50^{\circ} \mathrm{C}$ for $30 \mathrm{~min}$, about $50 \%$ of the antihemolytic activity was lost after heating at $60^{\circ} \mathrm{C}$; and was completely destroyed after heating at $80^{\circ} \mathrm{C}$ (Fig. 3A). Similarly, exposure of fraction $\mathrm{C} 1$ to $\mathrm{pH} 5$ or 8.8 for $2 \mathrm{hr}$ resulted in about $50 \%$ reduction of the antihemolytic activity, and exposure to extreme $\mathrm{pH}$ such as 2.8 or 12.5 resulted in a complete loss of the antihemolytic activity (Fig. 3B).

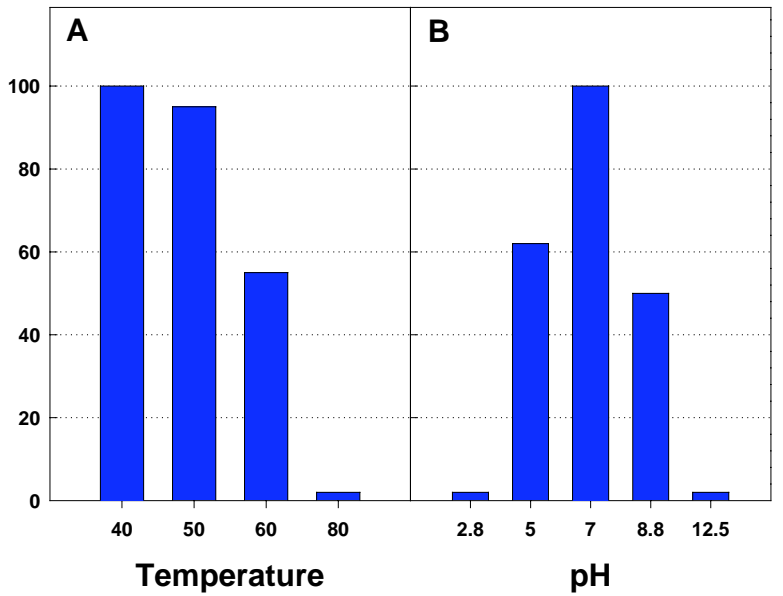

Fig. (3). A) Thermal stability of the antiviral activity. Samples containing $10 \mu \mathrm{g}$ of fraction $\mathrm{C} 1$ were incubated for $30 \mathrm{~min}$ at various temperatures and cooled before they were incubated with Sendai virions for $24 \mathrm{hr}$ at $30^{\circ} \mathrm{C}$. The hemolytic activity of the incubated mixture containing the Sendai virions was examined by an hemolysis assay as described. B) Stability of the antiviral activity at various $\mathrm{pH}$ values. Samples containing $10 \mu \mathrm{g}$ of fraction $\mathrm{C} 1$ were incubated with various buffer solutions having different $\mathrm{pH}$ values for $2 \mathrm{hr}$ at room temperature. Each mixture was titrated to $\mathrm{pH} 7$ by $0.5 \mathrm{M}$ phosphate buffer before incubated with Sendai virus and an hemolysis assay was carried out as described. Each experiment was performed twice and similar results were obtained.

As shown in Fig. (4A) and Fig. (4B), fraction C1 possesses azocollase, azocaseinase and gelatinase activities.

The finding that Echinibin-1, the antiviral factor isolated from Echis coloratus, is a metalloproteinase, indicated that specific proteolytic activity is needed for the inhibition of Sendai virus. Indeed, the antihemolytic activity of fraction C1 could be inhibited with $125 \mu \mathrm{g} / \mathrm{ml}$ EDTA, but not with 1 mM PMSF (Fig. 5), which indicate that the antiviral fraction is not a serine protease but rather a metalloproteinase. The specificity of $\mathrm{C} 1$ towards the viral components is the 30 -fold lower concentrations needed to digest the viral components (see below) than those needed $(30 \mu \mathrm{g} / \mathrm{ml})$ for complete digestion of azocoll or azocaseine (data not shown). In addition, while $1.2 \mu \mathrm{g} / \mathrm{ml}$ of fraction $\mathrm{C} 1$ inhibited $50 \%$ of the hemolytic activity of the virus (Table 1), a hundred-fold concentration of trypsin $(125 \mu \mathrm{g} / \mathrm{ml})$ did not affect the hemolytic activity of the virions.

SDS PAGE of Sendai virions under reductive conditions resulted in multiple bands with molecular weights ranging between 30 to $200 \mathrm{kDa}$ (Fig. 6c). Incubation of the virus alone at $30^{\circ} \mathrm{C}$ overnight did not change this profile (Fig. 6e).

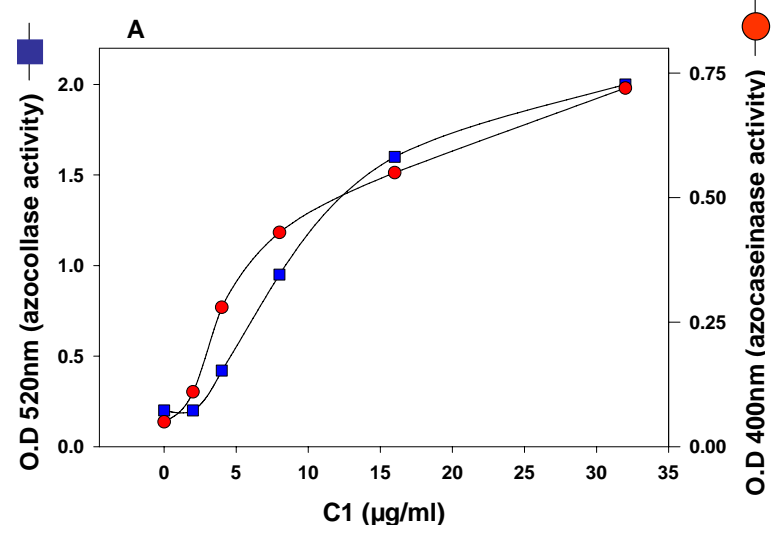

B

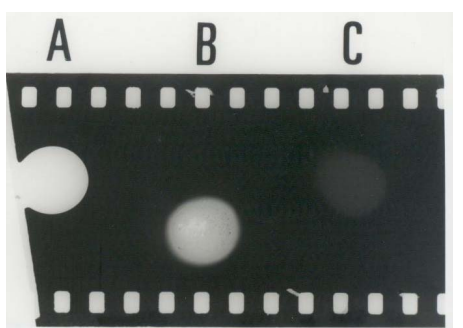

Fig. (4). A) Azocollase, azocaseinase and B) gelatinase activities of fraction $\mathrm{C} 1$ were examined as described in the methods section.

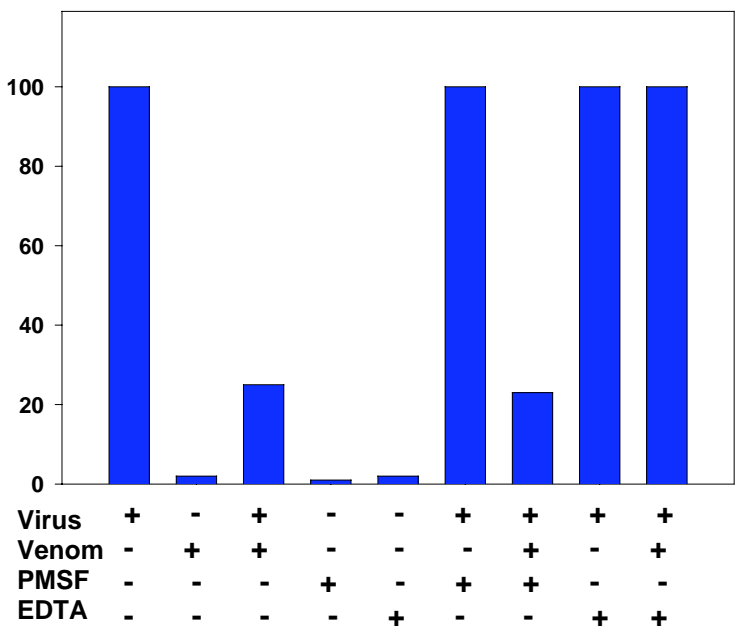

Fig. (5). Antiviral activity of fraction $\mathrm{C} 1$ after incubation with EDTA or PMSF. $10 \mu \mathrm{g}$ aliquots of the venom fraction $\mathrm{C} 1$ were incubated with $1 \mathrm{mM}$ PMSF or with $125 \mu \mathrm{g} / \mathrm{ml}$ EDTA for $1 \mathrm{hr}$ at $37^{\circ} \mathrm{C}$. Then, each mixture was incubated with the Sendai virions for $1 \mathrm{hr}$ before a hemolysis assay was carried out as described. PBS, EDTA or PMSF alone were added to the virions, as controls. Each experiment was performed twice and similar results were obtained.

However, incubation of the Sendai virions with fraction C1 resulted in the disappearance of several molecular weight bands already after $3 \mathrm{hr}$ of incubation (e.g. see arrows in Fig. 6). The longer the incubation period was, the stronger digestion of the viral bands occurred (Fig. 6g,i), indicating 
that the antiviral activity is related to the digestion of viral components.

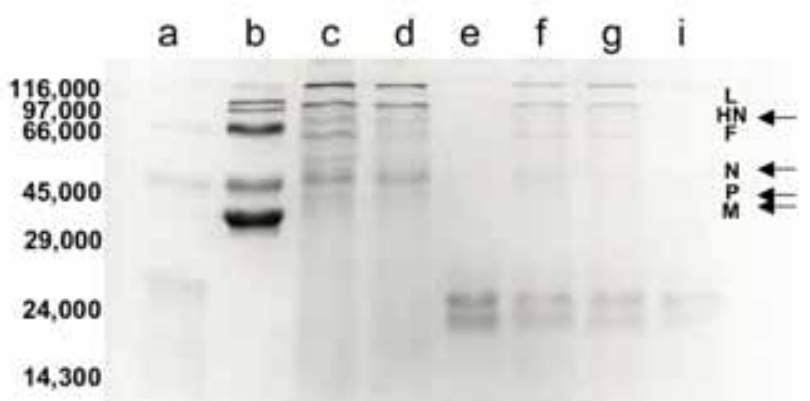

Fig. (6). SDS-PAGE of the Sendai virions incubated with fraction C1. Lanes a,b) markers with different Mol. wt; c) Sendai virus without pre-incubation; d) Sendai virus incubated overnight with PBS; e) Fraction C1 alone, without virions; f-i) Sendai virus incubated with fraction $\mathrm{C} 1$ for $20 \mathrm{~min}, 3 \mathrm{hr}$ and overnight, respectively. L- Large protein; HN- Hemagglutinin-neurominidase protein; F- Fusion protein; N- Nucleocapsid protein; PPhosphoprotein; and M- Matrix protein.

\section{DISCUSSION}

Among eleven viperid snake venoms that we screened for antiviral activity using a model of hemolysis of human erythrocytes by Sendai virus, the most powerful venoms were those of the snakes Echis coloratus and Echis carinatus sochureki [5]. A 25-kDa metalloproteinase antiviral factor, termed Echinibin-1, was isolated from the venom of Echis coloratus [6], which neutralizes Sendai virus by proteolytic digestion of viral components, including the HN glycoprotein responsible for the attachment of the virions to the target cells. The present work deals with the isolation of an antiviral fraction from the venom of Echis carinatus sochureki, another powerful antiviral venom [5]. The hemolytic activity of the Sendai virus is inhibited by more than 24 fold by the isolated active fraction $\mathrm{C} 1$ than by the crude venom. Further fractionation of this fraction with DEAE Sepharose resulted in a loss of the anti-hemolytic activity, indicating that all three fractions are needed for antiviral activity. SDS electrophoresis under denaturating conditions of $\mathrm{C} 1$ revealed that this fraction is composed of three bands with molecular weights of $18,23.5$ and $27.5 \mathrm{kDa}$. It is of interest that although Echis carinatus sochureki and Echis coloratus are closely related viper snakes, in the venom of the former snake a complex of 3 proteins is needed to neutralize the hemolytic activity of Sendai virus, while in the venom of the later, one protein, which exerts a similar mechanism of antiviral activity, is sufficient. The reason why these three factors do not show antiviral activity independently but only when they are combined is not clear, and further studies to elucidate the exact mechanism by which they exert their antihemolytic action are needed. Finding out if one on the three fractions obtained from the venom of Echis carinatus sochureki is similar to Echinibin-1, the antiviral protein isolated from the venom of Echis coloratus, should be investigated, for example by determining the sequence of the proteins, as well as by generating monoclonal antibodies against Echinibin-1 and determining its cross-reactivity with any of the three fractions now obtained from the venom of Echis carinatus sochureki.

As in the case of Echinibin-1, the antihemolytic activity is expressed only when the virions were pre-incubated with the active fraction. Once the virions were attached to the target cells, the antiviral fraction did not affect their following hemolytic activity.

Incubation of $\mathrm{C} 1$ with the virions, even for a short incubation of $20 \mathrm{~min}$, resulted in the degradation of several viral protein bands. The hemagglutinin-neuraminidase (HN), matrix (M), phosphoprotein $(\mathrm{P})$ and nucleocapsid $(\mathrm{N})$ were completely digested already after 20 minutes of incubation. Longer incubation (overnight at $30^{\circ} \mathrm{C}$ ) resulted in degradation of almost all viral protein bands. This included the large-polymerase (L) and fusion (F) glycoproteins, as the high molecular weight bands, corresponding to these glycoproteins disappeared (Fig. 6i).

Interestingly, all bands, including those that represent the C1 fraction, fade over time, indicating a possible auto- and general proteolytic activity of the isolated proteins. Furthermore, no small molecular weight bands appear in the Coomassie blue stained gel (Fig. 6) as well as in additional such similar experiments (data not shown), suggesting nonspecific degradation of small proteins by the isolated $\mathrm{C} 1$ fraction. However, previously we did not find any correlation between the general proteolytic activity of several whole viperid venoms and their capacity to inhibit Sendai virus hemolytic activity [5]. Incubation of Sendai virus with 100 fold higher concentration of trypsin $(125 \mu \mathrm{g} / \mathrm{ml}$, compared to the $\mathrm{IC}_{50}$ of $1.2 \mu \mathrm{g} / \mathrm{ml}$ the active fraction), did not inhibit the hemolytic activity of Sendai virus. This result points to the increased specificity of the antiviral activity of fraction $\mathrm{C} 1$, rather than general strong proteolytic activity, as found in other venoms [5] or trypsin. The proteolytic and antihemolytic activities of the isolated fraction $\mathrm{C} 1$ were inhibited by EDTA but not by PMSF, indicating that the active fraction is a metalloproteinase.

Future studies should further characterize the proteolytic activities of fraction $\mathrm{C}$, which seems to possess sequence specificity. These studies should include purifying and sequencing the polypeptide fragments resulting from proteolysis. In addition, the capacity of fraction $\mathrm{C} 1$ to inhibit the hemolytic activities of other Sendai virus strains or of other viruses in other viral genus (e.g. Influenza A, New Castle Disease virus, etc.), should be studied.

\section{CONCLUSIONS}

This manuscript describes the isolation and partial characterization of a protein proteolytic fraction isolated from the venom of Echis carinatus sochureki, using Sendai virus as a substrate. The isolated fraction, $\mathrm{C} 1$, inhibits the hemolytic activity of Sendai virus through a mechanism of proteolysis in similar to that of Echinibin-1, a protein isolated from the venom of a closely related viper snake - Echis coloratus. It is therefore not surprising that the antiviral factors found in two closely related species have similar mechanisms of activity. 


\section{REFERENCES}

[1] Chaim-Matyas A, Borkow G, Ovadia M. Isolation and characterization of a cytotoxin P4 from the venom of Naja nigricollis nigricollis preferentially active on tumor cells. Biochem Int 1991; 24: 415-21.

[2] Dufton MJ, Hider RC. In: Harvey AL, Ed. Snake Toxins. NY, Pergamon Press 1991; 259-302.

[3] Chaim-Matyas A, Ovadia M. Cytotoxic activity of various snake venoms on melanoma, B16F10 and chondrosarcoma. Life Sci 1987; 40: 1601-7.

[4] Mollmann U, Gutsche W, Maltz L, Ovadia M. Activity of cytotoxin P4 from the venom of the cobra snake Naja nigricollis on grampositive bacteria and eukaryotic cell lines. Arzneimittelforschung 1997; 47: 671-3
[5] Borkow G, Ovadia M. Inhibition of Sendai virus by various snake venom. Life Sci 1992; 51: 1261-7.

[6] Borkow G, Ovadia M. Echinhibin-1--an inhibitor of Sendai virus isolated from the venom of the snake Echis coloratus. Antiviral Res 1994; 23: 161-76.

[7] Borkow G, Ovadia M. Selective lysis of virus-infected cells by cobra snake cytotoxins: A sendai virus, human erythrocytes, and cytotoxin model. Biochem Biophys Res Commun 1999; 264: 63-8.

[8] Murray PR, Rosenthal KS, Kabayashi GS, Pfaller MA. Medical Microbiology. $3^{\text {rd }}$ ed. St. Louis: Mosby; 1998; 462-471.

[9] Kingsbury DW. In: Fields BN, Knipe DM, Eds. Virology 4/e. NY, Raven Press 1990; 945-962.

[10] Laemmli UK. Cleavage of structural proteins during the assembly of the head of bacteriophage T4. Nature 1970; 227: 680-5.

(C) Borkow et al.; Licensee Bentham Open.

This is an open access article distributed under the terms of the Creative Commons Attribution License (http://creativecommons.org/licenses/by/2.5/), which permits unrestrictive use, distribution, and reproduction in any medium, provided the original work is properly cited. 